\title{
The use of sand deposits in buildings for energy storage
}

\author{
Pawel Ratuszny* \\ University of Opole, Independent Department of Process Engineering, \\ ul. Dmowskiego, 7-9, 45-365 Opole, Poland.
}

\begin{abstract}
The aim of the research is to prepare data for the design of heat stores with sand filling. In buildings without basement, spaces between foundation walls are filled with material easily compacted, which forms a solid and durable basis for the ground level of the building. As a rule, this material is sand of various grain size, and foundation walls are insulated.

In this way, a space filled with a granular material is formed, which, with a properly designed heat exchanger attached, may be used as sensible-heat storage. Such a store makes a good lower level source for heat pumps source of heat at the time of low temperatures outside, which significantly raises the coefficient of efficiency of the system. Low construction cost of the heat exchanger is an additional argument for the use of the space between the foundation walls for the purpose of building a heat store.

This paper presents the results of studies that allow of the appropriate design of the heat exchanger in a heat store with a granular deposit. The deposit temperature changes in time have been studied, dependent on the distance from the source of heat and humidity of the material. Study was carried out for the sands used for filling the space between the foundation walls.
\end{abstract}

\section{Introduction}

Solar energy is not easy to use because of numerous inherent limitations. The main limitation is the difference in time between the highest efficiency of conversion of solar radiation and the greatest demand for heat. In solar power systems used for heating buildings, the difference is considerable both in daily scale, in the whole year, and in seasonal operations. The greatest heating demands occur in the evening, at night, and in the morning when solar radiation reaching the earth is low or equals zero. In Poland about $80 \%$ of yearly solar radiation occurs between March and October, when the heating demands are low. During the heating season barely $20 \%$ of solar energy can be stored [1].

Development of energy engineering, especially the one based on renewable sources must therefore go hand in hand with development of technologies of energy storing in various forms. Each energy transformation entails heat loss, which is due to the efficiency of the system. Therefore, the most efficient solution means storing energy in the same form as it has been collected, or as it will be utilised. Hence independent lines of research and

\footnotetext{
*Corresponding author: ratuszny@uni.opole.pl
} 
thermal, and biomass.

Thermal energy may be stored using sensible heat. This method requires the largest storage volume in relation to the amount of energy stored, but at the same time the system installation is easy and materials used are widely available. Other methods used on the greater or lesser scale for thermal energy storage are methods using phase change materials (PCM), thermochemical systems based on chemical reactions, or sorption processes. In all types of storage, the working substances may be liquids or solids, the latter can be monolithic or powdery.

In his research, the author studies thermal properties of granular beds in relation to their ability to store thermal energy. One of the essential properties of granular materials is the velocity of heat dispersal in the bed, dependent on such factors as the grain material, granulation, porosity, and humidity. Such stores can be constructed in the space between the foundation walls in the house, which is filled with sand.

The article presents the results of research which will help to determine the distance between the heat exchanger pipes in a sand-filled store. The research was conducted for a dry and humid deposit.

Given these factors it is possible to calculate technological parameters of the store, and with the changes in temperature of the deposit at the time of delivery/receiving heat given, the heat exchanger can be designed appropriately in such a store.

In this paper, the author presents the results of own research on temperature changes of the heated sand deposits of grain size 0,1-2,4 mm used for filling out spaces between the foundation walls in buildings It is proposed to use these spaces for building heat stores that serve as lower-source heat pumps.

\section{Review of publications on thermal energy storage in granular deposits.}

Numerous works have been published on physico-thermal properties of granular deposits, which form geological layers. However, studies have mainly been carried out into obtaining heat from the ground using vertical and horizontal probes, or the open storage of thermal energy - BTES (Borehole Thermal Energy Storage). In such systems energy is stored in rock or soil. The exchanger pipes are placed in holes bored in the existing ground. The quantity and depth of the boreholes depends on the amount of heat required, and on the properties of the soil. Most common diameter of the hole is $150 \mathrm{~mm}$. The space between the walls of the holes and the U-tubes is filled with cement slurry of high conductivity. BTES systems consist of one up to hundreds of heat exchangers, spaced radially from the center to the edges. The holes are most often spaced about $2-5 m$ from each other, and their depth varies from a dozen or so to $300 \mathrm{~m}$ [2].

In the beginning, the studies on ground systems were only carried out to find out about the possibilities to use the land for heat pumps, as a natural source of thermal energy. Only at a later period emerged an idea to probe the possibilities of storing this energy in ground. The development of storing thermal energy in ground was influenced / incited / initiated greatly by the development of solar power engineering. In such stores ground is separated into two centers: storage and insulation, i.e. the storage ground is surrounded by the insulating ground.

Almost any soil type can be used for a thermal energy store, ranging from sands to crystalline rocks. However, geological surveys must be done in the site that is intended to be used as an accumulator, mainly with regard to lithology, density of the rocks, the capacity and thermal conductivity, soil water content, and porosity. Table 1 presents thermal capacities of a given ground $1 \mathrm{~m}^{2}$ for vertical heat exchangers. It is important not 
to overestimate the volume of the power needed so as to avoid boring too many holes and the excess costs incurred [2].

Table 1. The power obtained from the ground by a vertical heat exchanger [3]

\begin{tabular}{|l|c|c|}
\hline \multirow{2}{*}{ Soil type } & \multicolumn{2}{|c|}{ Power obtained, $W / m$} \\
\cline { 2 - 3 } & $\begin{array}{c}\text { at } 1800 \text { hours of system } \\
\text { operation }\end{array}$ & $\begin{array}{c}\text { at } 2400 \text { hours of system } \\
\text { operation }\end{array}$ \\
\hline Dry gravel, sand & $<25$ & $<20$ \\
\hline Saturated gravel, sand & from 60 to 80 & from 55 to 65 \\
\hline $\begin{array}{l}\text { Heavily water saturated sand, } \\
\text { gravel }\end{array}$ & from 80 to 100 & from 80 to 100 \\
\hline clays and silts & from 35 to 50 & from 45 to 40 \\
\hline Limestone & from 55 to 70 & from 55 to 65 \\
\hline Sandstone & from 65 to 80 & from 55 to 70 \\
\hline Acid igneous rock & from 65 to 85 & from 35 to 55 \\
\hline Alkaline igneous rock & from 40 to 65 & from 60 to 70 \\
\hline Gneiss & from 70 to 85 & \\
\hline
\end{tabular}

During the summer season, excess heat, e.g. from solar panels, is transported in the fluid from the centre to the edges of the system of exchangers. In this way, heat is gradually transported to the ground, and the temperature in centre of the system is higher than on the edges. In the heating (winter) season the system is reversed. The cold fluid is transported out of the centre of the system, collecting slowly the heat from the ground store and increasing the temperature [3].

Polish soils are mostly loose or cohesive, and can make good, cost-effective energy stores depending on their thermal parameters, the degree of soil water content, and the structure of the soil. Most loose soils are in lake regions and in the west of Poland. In the north, and in the central part of Poland, the most common soil is cohesive, in the south it is also common, however, with the exception of the mountains [4].

Knowledge of soil thermal conductivity is fundamental to understand heat transfer in soils. Experimental studies in this area have been carried out using a thermo probe method. Zhang et al. proposed a new method to measure sand thermal conductivity dryout curves using a new thermo-TDR probe. Thermo-time domain reflectormetry (TDR) probe integrates dual-probe heat pulse device with TDR technique for simultaneous measurements of soil water content, electrical conductivity, and thermal properties. [5]

For storing heat in ground on a small scale, a membraneless heat exchanger can be used. This invention was made and patented at Wrocław University of Technology. The idea behind was that in the climatic zone of Poland, the temperature of the ground at the depth of 4 - $5 \mathrm{~m}$ remains unchanged at about $+10( \pm 1,5)^{\circ} \mathrm{C}$. By placing a filling of a certain capacity at this depth, it is possible to create a solution where the air is initially heated in the winter season, and cooled in the summer season using the direct flow of air through the granular bed. [6]. Due to considerably lower coefficients of heat penetration, this solution can practically only be used in small systems used for ventilation purposes. [7]

In work [8] the authors found, having compared experimental data delivered by different authors that the system of equations derived from the traditional thermal resistance capacity model (TRCM) is usually stiff and leads to unstable results unless it is used for very small time steps which can increase the computation time significantly. The thermal resistance method was proposed, which is a simplified version of the TRCM, named as STRCM. The STRCM gives accurate and stable results even for time steps as large as one hour.

Also the $2 \mathrm{D}$ model was extended to $3 \mathrm{D}$ model. The results obtained through the $3 \mathrm{D}$ STRCM are compared with two experimental reference data sets and good agreement is 


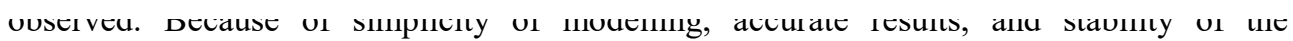
numerical solution, the STRCM method can be implemented in building simulation software.

The review of soil thermal conductivity models has been done in publication [9]. The authors reviewed thirteen alternative soil thermal conductivity predictive models, and assessed them with respect to the advantages, disadvantages and application conditions. Comparative model performance on sands was also conducted by predicting sand thermal conductivity and comparing it with the measured values collected from literature. The conclusion was that Zhang et al.[5], Chen [10] and Haigh [11] models are highly recommended for predicting sand thermal conductivity for geothermal applications.

The results of studies into thermal conductivity of materials used in building construction has been presented in work [12]. A transient asymmetrical hot plate device was constructed to characterize the thermal effusivity. Experimental measurement of the specific heat capacity using the Differential Scanning Calorimeter (DSC) and measurement of apparent density enabled the estimation of the volumetric heat capacity of the aggregates. The authors tested pouzzolan which is available in the Littoral region of Cameroon as a local construction material - earthen bricks, used for building homes. The work presents experimental thermal properties of a controlled mixture, as well as the influence of the particles' diameter on the thermal capacity, thermal conductivity, and thermal efficiency of the material. A house built of cinder block black or red pouzzolan will provide better insulation than a house built of ordinary concrete blocks (sand/cement). In view of natural air conditioning, building with composite materials made only for saving energy. Thus, for countries in tropical regions such as Cameroon, the use of pouzzolan aggregate, either as main material (controlled particle size with respect to the type of work to be performed) or as additive material, could simply optimize the thermal insulation of a building.

Specific heat capacity is usually tested with a calorimeter. One kind of calorimeter for defining specific heat capacity is used in the study [13]. A heat flow meter apparatus can be used for testing materials used in building construction. Tests using apparatus Fox 50 that runs on WinTherm50 software were presented in work [14]. The apparatus consists of upper and lower plates, two heat flow meters and a protective casing which prevents the heat losses. The sample to be measured is placed between the upper and lower plates. The upper plate is stationary and the lower plate moves vertically to provide good contact with the sample and minimize interface resistance. The authors have done measurements for the different materials used in construction, and by comparing compliance of measurements with data from the literature, they have demonstrated the usefulness of application of this method for construction materials.

In study [15] it was demonstrated, that using HDPE sand in lightweight composite mortars improves the energy performance of buildings. Polyethylene has very low thermal properties and its use in cementitious materials implies an improvement in thermal insulation. The mechanical properties of such concretes are naturally slightly poorer than of concretes without additives, however it is the environmental aspect that is crucial here: the possibility of utilisation of HDPE refuse. Due to a poorer thermal conductivity of HDPE sands and concretes made of them, it is advisable to consider the possibility of their application in construction of thermal stores as the outer layer, between the surroundings and the actual deposit of the thermal store.

The results presented in this study apply to thermal stores in residential buildings. They are determined by the material used, temperature range, and the store capacity, i.e. the volume of the space between the foundation walls of the building. Deposits of grainy sand can be used to store energy in a wider temperature range, for example. in concentrated solar power (CSP). The testing results of such systems are presented in [16]. It was found that the 
energy storage using HitecJ-saturated sand can be $4.5 \%$ higher than that of concrete, which may have cracks. This performance increase can result in appreciable reduction in costs of the thermal storage system. As a result, HitecJ-saturated sand is recommended to replace concrete as the thermal storage media in high temperature thermal storage $\left(>400 \_\right.$C).

The amount of thermal energy accumulated in a homogeneous material depends on its specific heat, temperature changes, and the amount of heat-accumulating material according to the following formula:

$$
Q=m \int_{T 1}^{T 2} c_{w}(T) d T
$$

In order to design a thermal store of bulk materials, it is necessary to consider the nature of heat transfer in these materials. Different mechanisms will be applied for a deposit heated with a flowing liquid, and for a deposit with the pipe heat exchanger, in which the air is trapped in the voids between the grains. For such deposits where the particles are surrounded by stagnant fluid, heat transfer is assumed to occur in the vertical direction by the following mechanisms [17]:

1. Heat transfer through the fluid in the void space by conduction and by radiation between adjacent voids (when the voids are assumed to contain a non-absorbing gas).

2. Heat transfer through the solid phase.

a) Heat transfer through the contact surface of the solid particles.

b) Conduction through the stagnant fluid near the contact surface.

c) Radiation between surfaces of solid (when the voids are assumed to contain a nonabsorbing gas).

d) Conduction through the solid phase.

Mechanisms 1 and 2 are parallel with each other. Conductivity is given by $k \varepsilon=(\Delta T / \Delta L)=$ heat flux in void space + heat flux through solid phase; Therfore [17]:

$$
-k_{\varepsilon} \frac{\Delta T}{\Delta L}=-k \varepsilon \frac{\Delta T}{\Delta L}+\alpha_{r v} \varepsilon(-\Delta T)
$$

Allowing for the temperature drop in the particle which is the sum of temperature drop in the solid phase and temperature drop near the contact surface, and flux in the solid phase, a general heat transfer equation for a granular deposit in which the fluid is stationary can be applied: (by stagnant fluid) [17]:

$$
k_{\varepsilon}=\varepsilon\left[k_{g}+\alpha_{r v} \Delta L\right]+\frac{(1-\varepsilon) \Delta L}{\frac{1}{k_{g} / l_{v}+\alpha_{p}+\alpha_{r s}}+\frac{l_{s}}{k_{s}}}
$$

In conclusion, it must be noted that a thermal store of the space between the foundation walls is of a different nature, and a simple application of models used for soil deposits, or even such parameters as specific heat, or heat conductivity, may produce divergent results. 
not transfer into the adjacent layers of soil, and when the store is considerably cooled, the heat will be collected from the ground under the building. Moreover, the exchanger is placed not in the existing soil deposit but in a bed of specially selected and arranged material (poured and compacted) during the construction of the building. It is therefore possible to select and design the store in such a way as to use the space under the building in a most effective way. I this context, it is proposed that the studies to be carried out should be comprehensive - for particular materials used for filling out the foundations of the building, and temperature distribution during the heating / cooling of the deposit should be adopted as the main design parameter.

\section{Concept of a thermal store between the foundation walls of a building}

In buildings without a basement the space between the walls of the foundation is filled out with a material easy to compact and giving a permanent and stable basis for the floor. The material used most commonly is sand. It is easy to calculate that for a house of a footprint area of $150 \mathrm{~m}^{2}$ and a combined foundation walls height of about $1.2 \mathrm{~m}$, the space to be filled out with sand is of about $160 \mathrm{~m}^{3}$. This material can be used for thermal energy storage (TES). Based on data from the literature cited above, assuming the volumetric heat capacity at $1.2-1.5 \mathrm{MJ} /\left(\mathrm{m}^{3} \mathrm{~K}\right)$ and temperature difference of $50 \mathrm{~K}$, a storage of heat capacity about $10.800 \mathrm{MJ}$ can be obtained.

When it comes to energy demands, the values to be used are to be computed in accordance with the procedures developed for calculating the energy performance of the building [18]. Although the technical requements for residential buildings in Poland state that the EP coefficient should be $95 \mathrm{kWh} /\left(\mathrm{m}^{2} \cdot\right.$ year), (as of 2021 to be lowered to 70 $\mathrm{kWh} /\left(\mathrm{m}^{2} \cdot\right.$ year $)$, new designs and technologies already in use in Poland allow to construct energy-efficient buildings of a coefficient ranging from 30 to $50 \mathrm{kWh} /\left(\mathrm{m}^{2} \cdot\right.$ year $)$. For such a house, a yearly energy demand amounts to about 25.000 MJ.

Comparing thermal capacity of the sand bed under the building with the energy demands of the building, we have a store that can meet at least half of its annual demand for thermal energy. It should be noted that in Poland this store can supply heat for about 8 months, with the largest heat consumption for 4 months only. The greatest energy charging of the store from the solar installation is carried out for about 5 months, but even during the winter, on sunny days, the store can also be charged. The second source of heat is the ground under the storage/building.

Given the above calculations, one can ask the question whether this is a worthwhile investment, as it does not fully cover the heat demand of the building.

The answer is not easy and can only be offered for a given building. It should be noted that the deposit of sand which can be used as a heat storage has to be made anyway as it makes the base for the floor in the building with no basement. Additional costs are incurred to cover the installation of the heat exchanger of pipes PE-X, bulk boxes, pump and control systems. The thicker thermal insulation of the foundation walls can also raise the costs. The total investment will increase the construction costs by $1-2 \%$. Cost of boreholes for vertical probes is about 10 times higher. In some cases, he cost of a horizontal ground heat exchanger may be comparable with the construction of the heat exchanger in the store under the floor - but only when the area around the house is be raised by additional brought 
soil. If earthworks are needed (excavation to place the exchanger pipes), the cost the horizontal ground heat exchanger becomes several times higher.

It is therefore proposed to use the space between the foundation walls of the building with no basement for construction of a heat store used as the lower source for the heat pump. To increase the efficiency of the system, it should be equipped with a heat pump of special design with two heat exchangers on the lower source, so that the pump would work in the air/water mode, and at low temperatures, when the coefficient of pump efficiency (COP) is low, the pump would switch to the brine/water operating mode by using the heat from the lower heat storage.

\section{Experiment and measurements methods}

The key issue for the design and building of a heat store is the appropriate selection and placement of the bed, and the appropriate design of the heat exchanger. In stores built under the building the bed is made of the compacted sand. Taking into account the transfer mechanisms described above, the compaction of the deposits is conducive to heat exchange because it reduces/removes the free spaces between grains thus increasing the heat transfer (conduction). The space is to be filled out with sand available locally, because the transport of another material would unnecessarily increase in the cost of investment.

The appropriate design of the exchanger will have therefore the greatest impact on the operation of the heat pump. In order to determine the piping spacing, both vertically and horizontally, measurements should be carried out for the specific material used for the construction of the store, in the conditions of operation of that store.

In this project, temperature changes have been studied in a heated granular deposit in relation to the degree of its humidity.

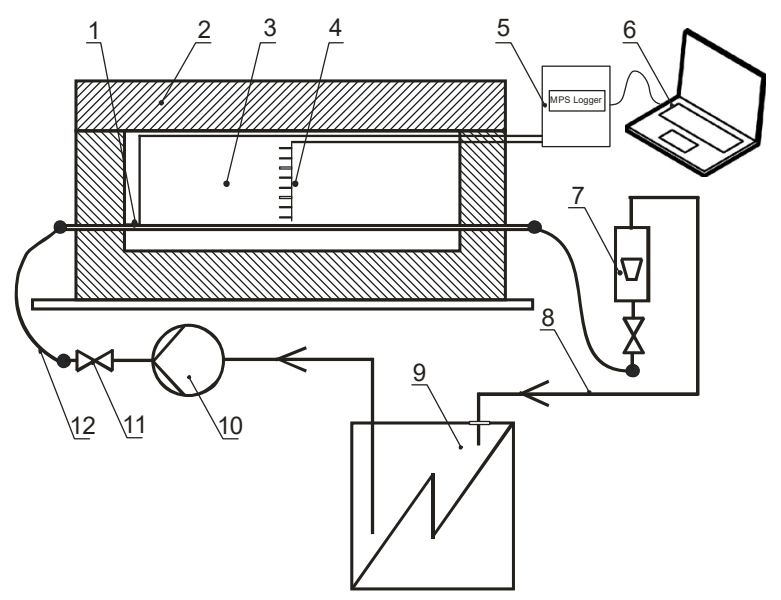

Fig. 1. The design of the laboratory workstation: 1 - pipe heating the deposit equipped with the inlet temperature sensor PT-100, 2 - thermal insulation of the measuring chamber, 3 - measuring chamber filled with loose material, 4 - temperature sensors TS-2 DM (8 pieces), 5 - measuring unit with MPS Logger, 6 - computer working with measuring module, 7 - rotameter, 8 - return of the heating water, 9 - electric thermostatic water heater, 10 - circulating pump, 11 - valve, 12 - flexible cable connecting the units of the workstation. 


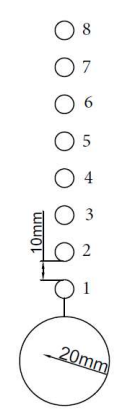

Fig. 2. Linear settings diagram for the around the heating pipe.

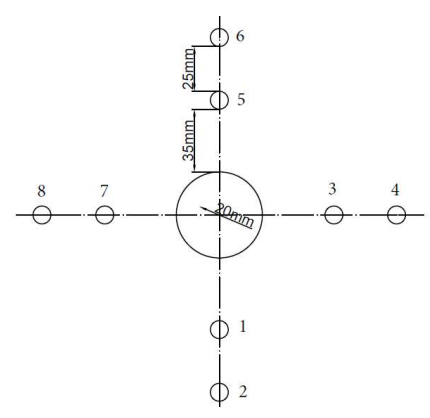

Fig. 3. Crosswise settings diagram for the sensors sensors in relation to the heating pipe.

A system for measuring tests results was constructed, as shown in fig. 1. It consists of the measuring chamber filled with the tested granular material, the heat supply unit of a boiler with a thermostatic temperature control system for the feed water, and a measuring unit for measurement of the flow of the liquid and the temperature in various areas of the deposit.

Temperature measurement was based on a measuring and control unit with a data logging function, configured for multi-point measurement and temperature monitoring. In the project, the control device was connected to eight TS-2 DM digital temperature sensors and one PT-100 sensor for monitoring the temperature of feed water as it may exceed the measuring range of TS-2 DM sensors. Figure 2 shows a diagram of the linear sensor settings. In this setting, temperature changes in the heated deposit were measured at different distances from the heating pipe. Figure 3 shows crosswise settings schema for the sensors around the heating pipe. This system was used to check if the bed heats up evenly in all directions. In the previous projects, the symmetry of the system was studied with a thermal imaging camera [19], and here additional measurements were made in order to unequivocally confirm the assumptions.

Tests were carried out for the deposits of sand 0,1-2,4 mm: dry, and at about $16 \%$ moisture content. The test chamber was filled with sand, and temperature sensors were installed; sensor PT-100 was placed on the heating water inlet and digital sensors were positioned vertically at $15 \mathrm{~mm}$ intervals. This allowed to measure the change in temperature of the deposit depending on the distance from the place of heat supply. The heating water temperature was $65^{\circ} \mathrm{C}$.

\section{Tests results and discussion}

Using the sensor system shown in the figure 3 it was verified, that the temperature distribution around the heating pipes is symmetric. In subsequent studies, sensors were arranged in lines in order to measure the temperature more precisely at various distances from the heating pipes.

The graphs in figure 4 and figure 5 show the changes in temperature of the heated granular bed. On the bases of the results of the measurements, one can notice large differences in the distribution of temperatures between the bed dry and moist deposits. 


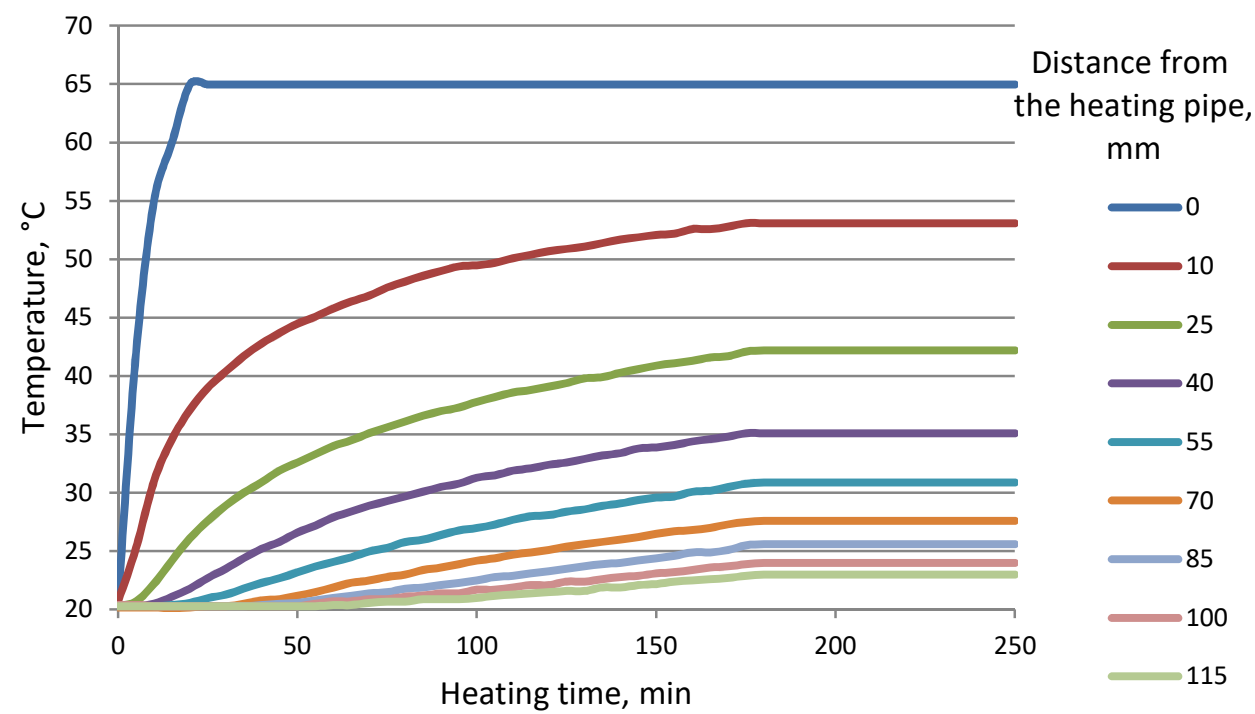

Fig. 4. Temperature chart for the deposit at different heights depending on the time of heating - sand 0,1-2,4 mm, dry

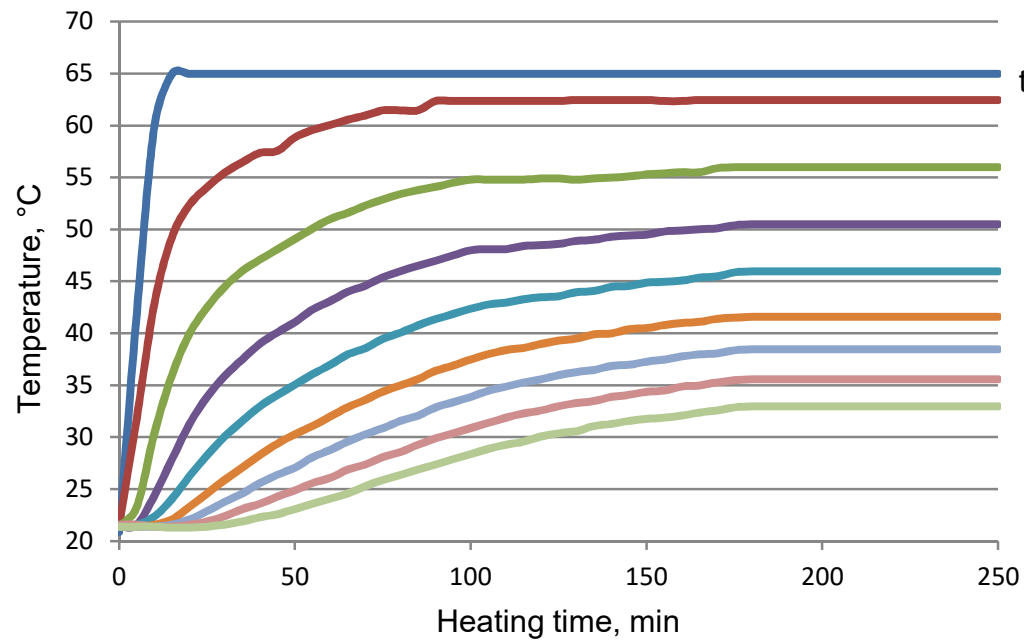

Distance from the heating pipe, $\mathrm{mm}$

Fig. 5. Temperature chart for the deposit at different heights depending on the time of heating - sand 0,1-2,4 mm, moist

The first observed difference is the maximum temperature of the deposit. In the nearest measurement point $(1 \mathrm{~cm}$ from the heating pip) the temperature of the dry deposits amounted to $53.1^{\circ}(\mathrm{C})$, while the $16 \%$ moisture bed heated up to $62.5{ }^{\circ} \mathrm{C}$, i.e. by $9.4{ }^{\circ} \mathrm{C}$ more, after the same measuring time. On the other sensors located above, the temperature difference ranged from 10 to $15.4{ }^{\circ} \mathrm{C}$, with higher temperatures reached by the wet deposit. The following graphs present the deposit temperature changes in relation to a given heating time. On the basis of the graphs in figure 4 and figure 5, three measuring times were selected. Initially - after 30 minutes; half-time of the total measuring time - after 90 minutes; and after 180 minutes, when the temperature has stabilised. 


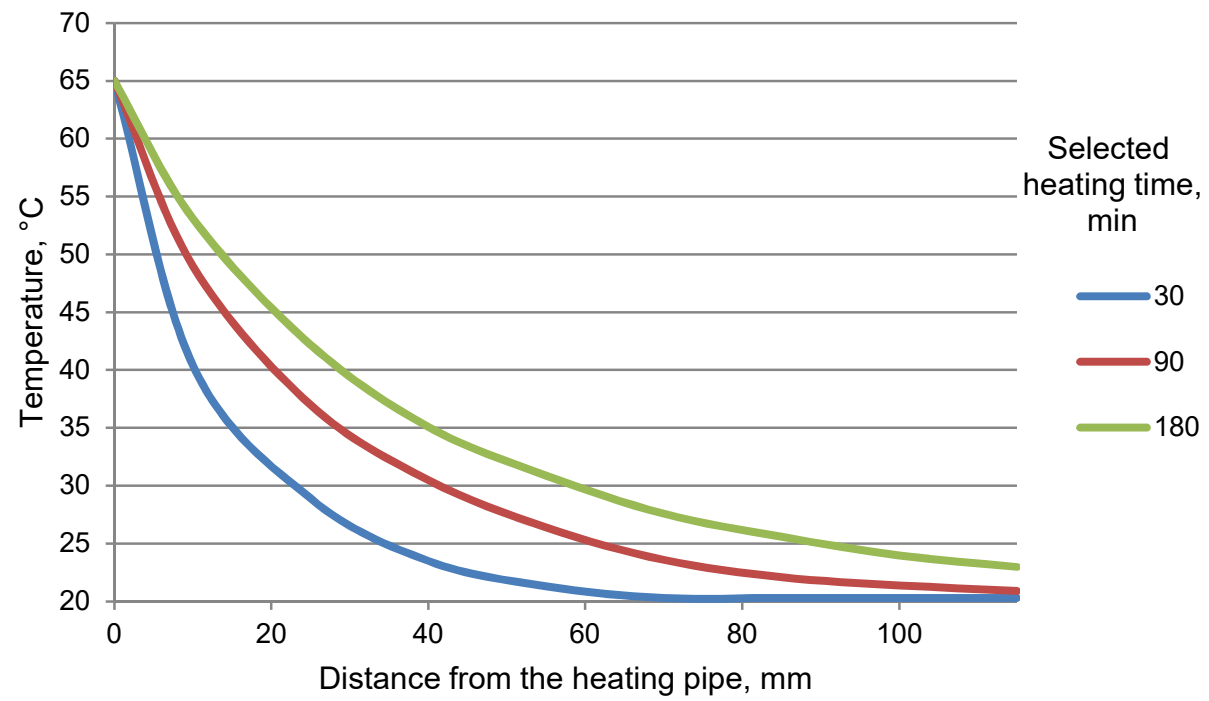

Fig. 6. Temperature curves after 30, 90, 180 minutes in the dry sand bed

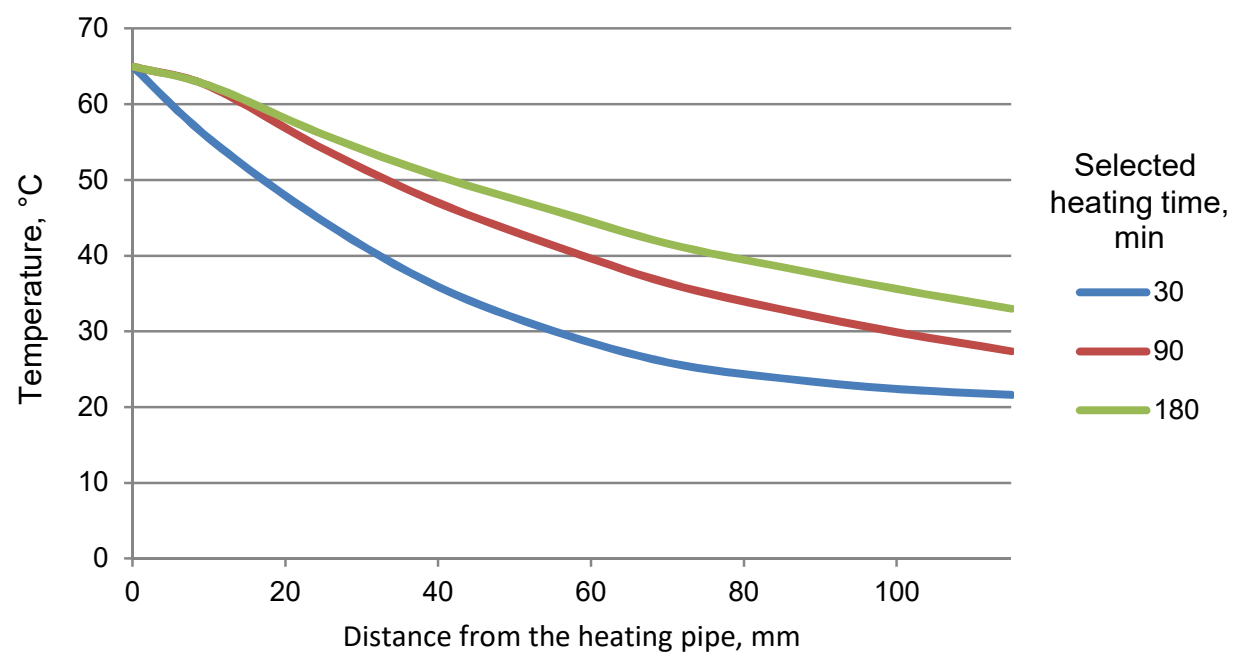

Fig. 7. Temperature curves after 30, 90, and 180 minutes in the moist sand bed.

Graphs in figure 6 and figure 7, show the change of temperature in the deposit. One can clearly see how quickly the deposit warms up and what temperatures can be obtained in different areas of the bed. The graphs also show the distances between the exchanger pipes for the assumed temperature of the bed. This the key information for the design of all systems, where the heat exchange takes place in granular deposits. By comparing the two charts we can see a clear impact of moisture of the deposits on the heating pace and the temperatures obtained. 


\section{Conclusions}

1. The space between the foundation walls of the building without basement filled with compacted sand is suitable for building a thermal energy store (TES).

2. The store can be used as the lower source for heat pump.

3. In order to design the heat exchanger in such a store, the knowledge of the heating curves of the deposit is essential.

4. Such curves should be determined for a specific kind of filling material and for the conditions for its implementation, it is also important to specify whether the deposit will be dry or slightly wet.

5. Construction of TES between the foundation walls of the building does not require a large investment, because the base for the floor, which has to be done anyway, is used as the filling material.

\section{Notation}

$Q$ - stored thermal energy [J],

$m$ - mass $[\mathrm{kg}]$,

$c_{w}$ - specific heat, $\mathrm{J} / \mathrm{kg} \cdot \mathrm{K}$

$T$ - temperature, $\mathrm{K}$

$k_{\varepsilon}$ - stagnant conductivity, that is effective thermal conductivity of porous media filled with stagnant fluid for both unconsolidated and consolidated particles, $\mathrm{W} / \mathrm{m} \cdot \mathrm{K}$

$k_{g}$ - thermal conductivity of fluid, $\mathrm{W} / \mathrm{m} \cdot \mathrm{K}$

$k_{s}$ - thermal conductivity of solid, $\mathrm{W} / \mathrm{m} \cdot \mathrm{K}$

$\Delta L$ - effective lenght between centers of two neighboring solid particles in direction of heat flow, $\mathrm{m}$

$l_{s}$ - effective lenght of a solid particle for heat transfer in a bed of unconsolidated particles, $\mathrm{m}$

$l_{v}$ - effective thickness of the fluid film adjacent to the surface of two solid particles, $\mathrm{m}$

$\alpha_{p}$ - heat transfer cofficient representing the heat transfer rate through the contact surface between solid particles in a bed of unconsolidated particles or between two clogged particles in a consolidated bed, $\mathrm{W} / \mathrm{m}^{2} \cdot \mathrm{K}$

$\alpha_{r v}$ - heat transfer cofficient for thermal radiation, void space to void space, $\mathrm{W} / \mathrm{m}^{2} \cdot \mathrm{K}$

$\alpha_{r s}$ - heat transfer cofficient for thermal radiation, solid surface to solid surface, $\mathrm{W} / \mathrm{m}^{2} \cdot \mathrm{K}$ $\varepsilon$ - void fraction of a packed bed of unconsolidated particles

\section{References}

1. Chwieduk D. Chwieduk M. Idea wykorzystania gruntu jako źródła ciepła i sezonowego magazynu ciepła. Instal, 12 (2016)

2. Miecznik M., Podziemne magazynowanie energii cieplnej-metody i zastosowania. Przegląd Geologiczny. 64, 7, (2016)

3. Cz. Oleśkowicz Popiel, Terenowy test termiczny gruntu dla pionowego gruntowego wymiennika pompy ciepła. Ciepłownictwo, Ogrzewnictwo, Wentylacja. 41/11(2010)

4. M. Tyszer, B.Tomaszewska, Geologiczne uwarunkowania oceny potencjału geotermii niskotemperaturowej w Polsce, Ciepłownictwo, Ogrzewnictwo, Wentylacja. 47, 7, DOI 10.15199/9.2016.7.2 (2016)

5. Nan Zhang, Xinbao Yu, Xuelin Wang, Use of a thermo-TDR probe to measure sand 
thermal conductivity dryout curves (TCDCs) and model prediction, International Journal of Heat and Mass Transfer 11, p. 1054-1064 (2017)

6. W. Cepiński, M. Besler, G. Besler, Bezprzeponowy gruntowy wymiennik ciepła i masy. Ciepłownictwo, Ogrzewnictwo, Wentylacja ${ }_{2} 42 / 3,(2011)$

7. E. Słodczyk, D. Suszanowicz, Optimization of Carbon Dioxide Concentration in the Didactic Rooms by the Regulation of Ventilation, Ecological Chemistry and Engineering. A, 23 (3), DOI: 10.2428/ecea.2016.23(3)27 ISSN 1898-6188 (2016)

8. A. Minaei, M. Maerefat, Thermal resistance capacity model for short-term borehole heat exchanger simulation with non-stiff ordinary differential equations, Geothermics 70 260-270 (2017)

9. N. Zhang, Z. Wang, Review of soil thermal conductivity and predictive models, International Journal of Thermal Sciences

Volume 117, July 2017, Pages 172-183 doi.org/10.1016/j.ijthermalsci. (2017)

10. SX. Chen, Thermal conductivity of sands. Heat Mass Transf, 44 (10) 1241e6 (2008)

11. SK. Haigh, Thermal conductivity of sands. Geotechnique, 62(7):617 -25,(2012)

12. J.C. Damfeu a, P. Meukam, Y. Jannot, Modeling and estimation of the thermal properties of clusters aggregates for construction materials: The case of clusters aggregates of lateritic soil, sand and pouzzolan, International Journal of Heat and Mass Transfer 102 407-416 (2016)

13. S. Drissi, A. Eddhahak, S. Care, J. Neji, Thermal analysis by DSC of phase change materials, study of the damage effect (March), J. Build. Eng. 1 13-19, (2015)

14. T. Ruuska, J. Vinha, H. Kivioja, Measuring thermal conductivity and specific heat capacity values of inhomogeneous materials with a heat flow meter apparatus, Journal of Building Engineering 9 135-14, (2017)

15. A. Badache, A. Soufiane Benosman, Y. Senhadji, M. Mouli, Thermo-physical and mechanical characteristics of sand-based lightweight composite mortars with recycled high-density polyethylene(HDPE), Construction and Building Materials 163 40-52, (2018)

16. B.Xua, J. Hana, A. Kumara, P. Lia,Y. Yangb, Thermal storage using sand saturated by thermal-conductive fluid and comparison with the use of concrete, Journal of Energy Storage 13 85-95 (2017)

17. D. Kunii, J.M. Smith, Heat transfer characteristics of Porous Rocks, A.I.Ch.E. Journal vol. 6, No.1, p. 71-78 (1960)

18. Rozporządzenie Ministra Infrastruktury i Rozwoju z dnia 3 września 2015 r. zmieniające rozporządzenie w sprawie szczegółowego zakresu i form audytu energetycznego oraz części audytu remontowego, wzorów kart audytów, a także algorytmu oceny opłacalności przedsięwzięcia termomodernizacyjnego, Dz.U. 2015 poz. 1606

19. P. Ratuszny, Wpływ właściwości fizycznych na transport ciepła $w$ złożu ziarnistym. Przemysł Chemiczny 96/9, s.1000-1002, DOI: 10.15199/62.2017.9.XX (2017) 